\title{
ARAP DILINDE TAHDÎD ÜSLÛBU VE TÜRKÇEYE ÇEVIRI PROBLEMI*
}

\author{
Hüseyin Ersönmez ** \\ E-mail: hersonmez46@gmail.com \\ ORCID ID: https://orcid.org/0002-7875-9960
}

Citation/C: Ersönmez, H. (2021). Arap dilinde tahdîd üslûbu ve Türkçeye çeviri problemi. Türkiye Din Eğitimi Araştırmaları Dergisi, 12, 301-316.

DOI Number: https://doi.org/10.53112/tudear.1016280

Öz

Bu çalışmamızda Arap dilinde "bir işi yapmayı veya yapmamayı güçlü bir şekilde istemek" olarak tanımlanan ve belli edatlar vasıtasıyla cümleye yansıtılan tahdîd üslûbu üzerinde durulmuştur. Tahdîd üslûbunun altında ele alınan oَ edatları ve bu edatların hangi durumlarda tahdîd ifade ettiği incelenmiştir. Zikri geçen edatların tahdîd ifade etmeleri için zâhiren veya takdîren muzâri fiilin başına gelmesi gerekmektedir. Bunun yanı sıra mâzi fiilin başına geldiği durumlarda cümle tahdîd anlamında kullanılmışsa mâzî fiil, muzâri fiile hamledilir. Ayrıca cümledeki tahdîd anlamı kullanılan kelimelerden, vurgulamadan ve bağlamdan da anlaşılır. Bunun yanı sıra tahdîd edatlarının her biri mürekkeb edat olup ayrı ayrı harflerin birleşmesinden oluşmuştur. Çalışmamızı tahdîd üslûbunun bu özellikleri çerçevesinde ele almaya çalıştık. Araştırmamızda tahdîd edatlarının mürekkep halinin yeni bir anlam kazanması durumunun Türkçeye aktarıırken göz ardı edildiğini tespit ettik. Özellikle bundan kaynaklı olduğunu düşündüğümüz nedenden dolayı da hedef dile tam anlamıyla yansıtılmadığını gördük. Bu durumu mealler üzerinden inceleyerek bazı çeviri önerilerini sunmaya çalıştık.

Anahtar Kelimeler: Arap dili ve belagatı, Türkçe, Çeviri, Tahdîd, Üslûp.

* Etik Beyan: Bu çalışmanın hazırlanma sürecinde bilimsel ve etik ilkelere uyulduğu ve yararlanılan tüm çalışmaların kaynakçada belirtildiği beyan olunur. Makale en az iki hakem tarafından incelenmiş, Turnitin kullanılarak benzerlik raporu alınmış ve araştırma/yayın etiğine uygunluğunu teyit edilmiştir. Ethical Statement: It is declared that scientific and ethical principles have been followed while carring out and writing this study and that all the sources used have been properly cited. The article was reviewed by at least two referees, a similarity report was obtained using Turnitin, and compliance with research/publication ethics was confirmed.

** Dr. Arş. Gör. İzmir Katip Çelebi Üniversitesi İslami İlimler Fakültesi, Temel İslam Bilimleri Bölümü, Arap Dili ve Belagatı $A B D$. 


\title{
TAHDID STYLE IN ARABIC LANGUAGE AND THE PROBLEM OF TRANSLATION INTO TURKISH
}

\begin{abstract}
This study deals with tahḍịd style which means burning desire to do or not to do something and it's particles that gives the tahdịị meaning. The particles ( مَلَّ - أَلَاَّ

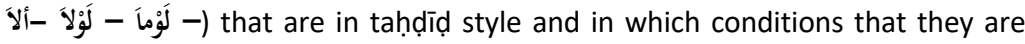
means taḥịị are examined. In this sense, the articles need seemingly or underlying imperfect verbs for tahdịid meaning. In addition to this, If they have been before a perfect verb, the verb alters its meaning to imperfect. tahḍị meaning is understood from words, stresses, context. tahḍị particles are composed from different particles. The present research has been run in the scope of the futures of tahdịị style. It is identified that combined tahdịị articles are neglected in the process of translation to Turkish and it is explored that they are not properly represented because of miss-translation. It is given some examples from Turkish Qur'an translations.
\end{abstract}

Keywords: Arabic language and retoric, Turkish, Translation, Taḥ̣ịị, Style.

\section{Giriş}

İnsanı diğer varlıklardan ayıran en önemli özelliklerden birisi dildir. Dil, insanların birbiriyle iletişimini sağlayan önemli bir araçtır. Dolayısıyla dilin doğru kullanımı da etkili bir iletişim için önem arz etmektedir. Dili doğru bir şekilde kullanmak o dilin belli kurallar çerçevesinde konuşulmasıyla mümkündür.

Bu kurallar bir dili doğru kullanmada belli bir öneme sahiptir. Aynı zamanda o dili başka bir dile aktarırken bu kurallarla birlikte anlamı da yansıtmak aynı derecede önemlidir. Bununla birlikte bir dildeki anlamı başka bir dile aktarırken aktarılan ifadenin kastettiği anlamı yansıtmak oldukça zordur. Bu bağlamda çeviri, bir ifadedeki anlamı hedef dile en iyi şekilde aktarmayı amaçlar. Çevirisi yapılan kelime ya da cümlelerin her iki dilde de anlamlarının iyi bilinmesi, kullanılan üslûplara ise dikkat edilmesi gerekir.

$\mathrm{Bu}$ anlamda çevirisi yapılırken dikkat edilmesi gereken meselelerden birisi de tahdîd üslûbudur. Arap dilinde "bir işi yapmayı ya da yapmamayı muhataptan güçlü bir şekilde istemek" olarak tanımlayabileceğimiz tahdîd üslûbu Arapçada belli edatlar vasıtasıyla yapılır. Muhataba verilmek istenen mesaj bu edatlar ile cümleye yansıtılır. Bu edatlar - edatlarından oluşmaktadır. Tahdîd üslûbu Arapçada bu şekilde kullanılmakla birlikte bu üslûbun kullanıldığı metinler Türkçeye aktarıldığında tahdîd üslûbuna çok dikkat edilmediğini görmekteyiz. 
Tahdîd üslûbunun kullanıldığı metinlerin Türkçeye aktarılması esnasında birtakım problemlerin ortaya çıktığını görmekteyiz. Çalışmamızda bu problemlere temas etmeye çalışacağız. Araştırmamızda ilk olarak tahdîd üslûbu, Türkçeye aktarılması ve bu üslûbun Arapçada nasıl kullanıldığı üzerinde durulacaktır. Daha sonra tahdîd ifade eden edatların diğer bazı anlamlarına da değinilecek hangi durumlarda tahdîd ifade ettiği örnekler üzerinden açıklanacaktır. Ayrıca tahdîd üslûbunun, edatları tek tek incelenerek cümleye kattığı anlamlar özellikle ayetler üzerinden örneklendirilerek açıklanacaktır. Bu üslûbun Türkçeye özellikle de meallere yansıtılmasında ortaya çıkan bazı problemlere işaret edilecek ve alternatif çeviri önerileri sunulacaktır.

\section{Tahdîd Üslûbu}

Tahdîd (حََْضِيض) "hadda" fiil kökünün tef'îl babında mastarı olup sözlükte "teşvik etmek, cesaretlendirmek, tahrik etmek" anlamlarına gelmektedir (ibn Manz̦ûr, 1414, s. 136; Zebîdî, t.y., s. 293). Tahdîd fiili sülâsi halinde Kurân-ı Kerîm’de de teşvik etmek

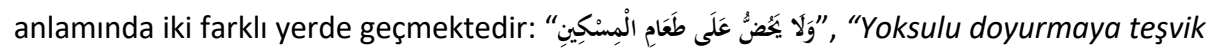
etmiyordu" (el-Hâkka, 69:34; el-Mâûn, 107;3). Ayrıca müfâ‘ale babında ise bir yerde geçmektedir: "وَلَا تَحَاضُونَ عَلَى طَعَام الْمِسْكِينِ", "Yoksulu doyurmak konusunda birbirinizi teşvik etmiyorsunuz" (el-Fecr, 89:18).

Terim olarak ise tahdid, "bir şeyi teşvikle istemek" şeklinde tanımlanır. Aynı terimle yakın anlamda kullanılan "arz" ise "bir şeyi nazikçe istemek" biçiminde tanımlanır (İbn Hişâm, 1985, s. 97).

"Tahdîd" ve "arz" anlam itibariyle birbirine yakın olsalar da arz bir şeyi talep etme bakımından tahdîdden daha yumuşak bir anlam ifade eder. Bu anlamda tahdîd bir fiilin yapılmasını istemede emir gibi kabul edilir (ibn Fâris, 1997, s. 140). Çalışmamızda her iki kavrama da işaret edilmekle birlikte özellikle tahdîd üslûbu üzerinde durulmuştur. ${ }^{1}$

Abbas Hasan tahdîdi şöyle tanımlar: "Bir şeyi yapmayı veya yapmamayı etkili bir şekilde istemektir. Etki ise etkileyici kelimelerin seçiminde ve seslerin vurgusunda ortaya çıkar" (Hasan, t.y., s. 512).

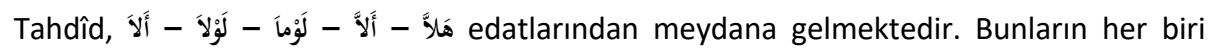
mürekkeb birer edat olmakla birlikte aslında ayrı ayrı harflerin birleşmesinden oluşmuştur.

1 Konuyla ilgili olarak Arap dünyasında yapılmış bazı çalışmalar şu şekildedir: Mürevvihh Nâyif Hasan erRıfâî, Esâlîbu'l-Arz ve't-Tahdîd ve't-Tenbîh: Dirâsetun Nahviyyetun Delaliyyetun fi'l-Kurâni'l-Kerîm (Yüksek Lisans), Amman, 2011; Huriye bt. Müferrec Sa'dî, -Levlâ- Envâuhâ ve Ahkâmuhâ'n-Nahviyye, Mecelletu Kulliyyeti Dâru'I-Ulûm, Kâhire, 2012, ss. 485-520; Muhammed Hâlid Abdurrâhmân Ahmed, Abdusselâm Muhammed Abdurrâhîm, Zâhiratu'-Tahdîd fi'l-Lugati'l-Arabiyye Dirâsetun Vasfiyyetun Tahlîliyyetun fí Dav'il'-Kurâni'l-Kerîm, ss. 7-22. 
Ortaya çıkan bu yeni edatlar da yeni anlamlar kazanmıştır. Bu edatlar aynı zamanda tevbîh, arz ve imtinâ ${ }^{2}$ edatları arasında da zikredilmiştir. Şöyle ki bu beş edatın hepsi tahdîd ifade etme noktasında ortaktırlar. Bunun yanı sıra ألاَ arz manasında da kullanılırken, لَوَ ise imtinâ edatı olarak da kullanılmaktadır (Zeccâcî, 1984, ss. 3-5; Ḥasan, t.y., s. 512).

Bu edatların tahdîd ve arz ifade etmeleri için kendilerinden sonra zâhiren veya takdîren

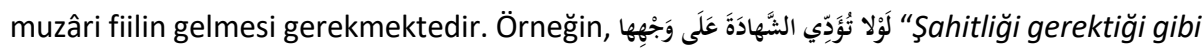
yapsaydın ya!" Bunun yanı sıra bu edatlardan sonra mâzî fiil gelirse tevbîh ifade eder. Örneğin; هَلًَ دَافَعَ الجُجبانُ عَنْ وَطَنِهِ فَانْتَصَرَ "Korkak! vatanını savunsaydı muzaffer olsaydı ya!”(Hasan, t.y., ss. 513-514).

Belirttiğimiz üzere bu edatlardan لَّ imtinâ edatı olarak da kullanılmıştır. Yani "bir şeyin olmamasının nedeni başka bir şeyin varlığının sebebinden dolayı" olmasıdır. Bu da iki durumda ortaya çıkar: Birincisi, bu edatlar haberi hazfedilmiş mübtedânın başına gelirlerse; ikincisi ise lafzen ve manen fiili mâzinin masdarının başına gelirse imtinâ ifade ederler. (Hasan, t.y., s. 515). Örneğin; لَوْما المُوَاءُ لَماتَ الَْحَحِياء "Hava olmasaydı canlılar ölürdü.." Burada canlıların ölmemesi havanın varlığından dolayıdır. Yani bir şeyin olmaması başka

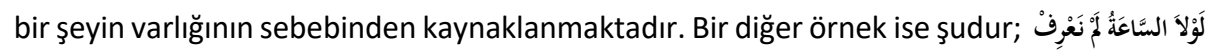
"Saat olmasaydı vakti bilemezdik." Aynı şekilde burada da vakitten haberdâr olmamı saatin varlığının sebebinden kaynaklanmaktadır.

İbnu'ş-Şecerî̀ye (ö. 542/1148) göre de tahdîd emir bahsine dâhil bir konudur. Edatları ise

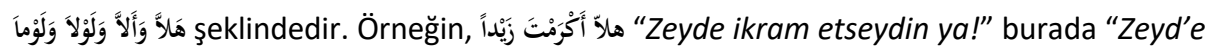
ikram et" anlamında emir vardır. Ayrıca İbnu'ş-Şecerî burada Antere b. Şeddâd'ın (ö. m. 614) muallakasından şu beyti örnek olarak vermiştir: (ibnu'ş-Şecerî, 2014a, ss. 425-426, 2014b, s. 543).

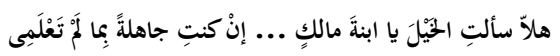

"Ey Mâlik'in kızı, bilmediğin şeyi atılıara sorsaydın ya!"

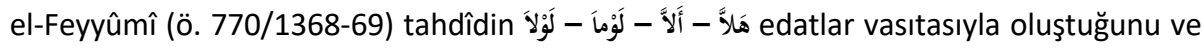
bunların gelecek zaman ifade eden fiillerin başına geldiğinde o fiilin yapılmasını teşvik etmek ve istemek anlamına geldiğini söylemiştir. Bununla birlikte mâzî fiilin başına geldiğinde ise fiilin terkinden dolayı tevbîh ifade ettiğini zikretmiştir (el-Feyyûmî, t.y., s. 76).

2 Bir şeyin bulunmasından (veya bulunmamasından) dolayı başka bir şeyin bulunmaması (veya bulunması) durumunu ifade eder. 


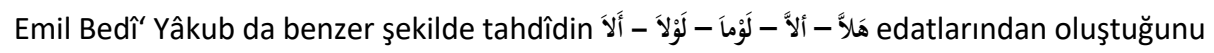
söylemiş ve tahdîdi "bir fiilin yapılmasını veya yapılmamasını güçlü bir şekilde istemektir" şeklinde tanımlamıştır. Ona göre bu harflerin tahdîd ifade etmeleri için kendilerinden sonra zâhiren veya takdîren gelecek zamana delalet eden bir fiili muzâri gelmesi şart

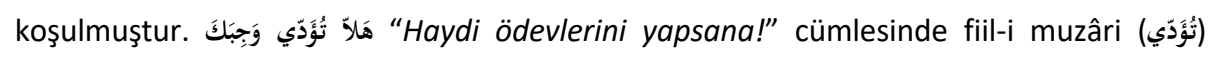

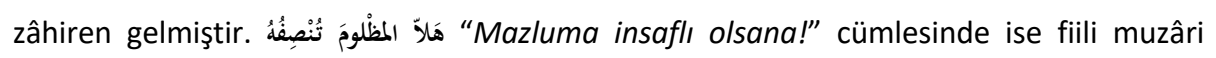
takdîren gelmiş olup aslı şeklindedir (Ya'kûb \& Âsî, 1987a, s. 360).

Şayet tahdîd edatları isim cümlesinin başına gelirse "يُكونُ gibi nakıs bir fiil-i muzâri takdîr edilir. es-Sımat b. Abdullah el-Kuşeyrî̀nin beytinde olduğu gibi:

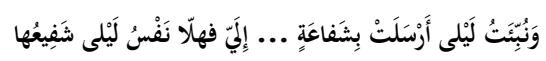

"Leylânın bir şefaatçi gönderdiği haber verildi bana. Keşke Leylâ'nın kendisi şefaatçisi olsaydı ya!"

Beytin takdîri فهلّا تَكونُ نَفْسُ كَيْلى شَفِيعِها "Leylânın kendisi şefaatçisi olsaydı ya!" şeklinde olup

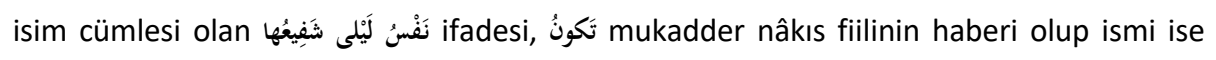
mahzûf şe'n zamiridir (Ya'kûb \& Âsî, 1987a, s. 361).

Bunun yanı sıra tahdîd edatları mâzî fiillerin de başına gelir ve bağlamda tahdîd varsa bu

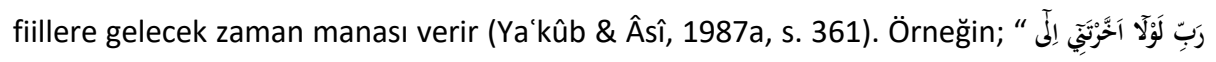

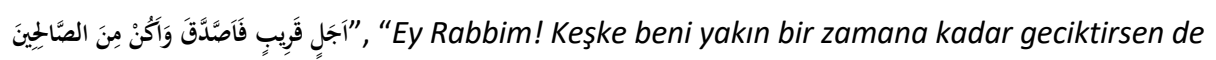

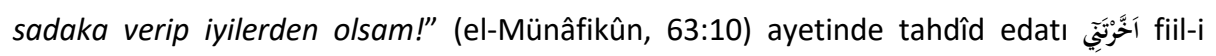
mâziinin başına gelmiş olmakla birlikte manası gelecek zaman ifade eder.

Meşhur belâgat âlimlerinden es-Sekkâkî (ö. 626/1229) ise tahdîdi temennî bahsinin altında ele alır. Şöyle ki, tahdîd ve temennî harfleri olarak isimlendirilen

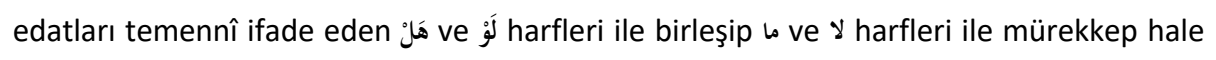

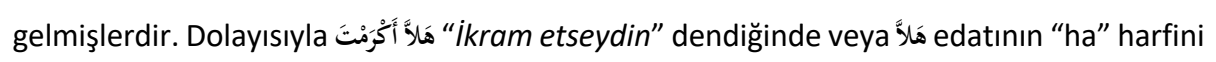

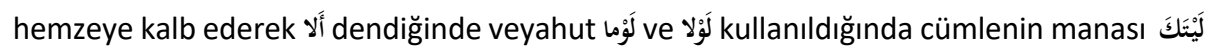

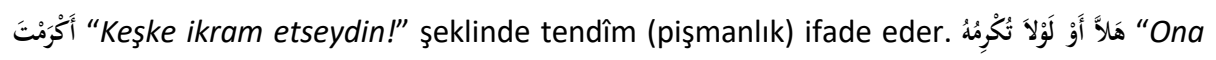
ikram etsen" denildiğinde ise mana كَيَكَكَ تُكْرِمُهُ "Keşke ona ikram etsen" anlamında istek bildirir (es-Sekkâkî, 1987, s. 307).

Tahdîd üslûbuyla ilgili olarak buraya kadar verdiğimiz bilgilerden hareketle genel olarak diyebiliriz ki, zikri geçen edatların tahdîd ifade etmeleri için zâhiren veya takdîren muzâri fiilin başına gelmesi gerekir. Bunun yanı sıra mâzi fiilin başına geldiği durumlarda cümle tahdîd anlamında kullanılmışsa mâzî fiil muzâriye hamledilir. Ayrıca cümledeki üslûbun 
tahdîd ifade ettiği ise kullanılan kelimelerden, vurgulamadan ve bağlamdan anlaşılır. Tahdîd üslûbuyla alakalı bu bilgileri verdikten sonra zikri geçen edatları tek tek ele alarak bunların özellikle mealler üzerinden Türkçeye çevirisini aktararak meallerdeki yansımalarını incelemeye çalışacağız. Bu anlamda birçok meal incelenerek bunlar arasında toplumda yaygın olarak kullanılanlardan beş tanesini örnek olarak vermeye çalışacağız. Illgili meallerin çevirilerine ek olarak bu üslûbu daha iyi yansıttığını düşündüğümüz bazı alternatif çeviriler sunmaya gayret edeceğiz.

\section{Tahdîd Edatları ve Türkçeye Çevirisi}

\section{1. ألا}

Tahdîd ve arz ifade eden أَأ, hemze (أ) ve nâfiye (olumsuzluk) lâ (لأ)'sının birleşmesiyle ortaya çıkan mürekkep bir edattır. er-Rummânî (ö. 384/994) edatın arz, tahdîd ve tenbîh gibi üç farklı anlamına değinmiştir (er-Rummânî, 1425, ss. 157-158). Bunun yanı sıra edatın temennî ifade ettiği de aktarılır (el-Murâdî, 1992, ss. 381-383). İbn Hişâm (öl. 761/1360) bu edatın beş farklı manaya geldiğini söylemiştir. Bunlar tenbîh, tevbih-inkâr, temennî, nefyi istifhâm ve arz-tahdîddir. Edatın içerdiği bu manalardan arz ve tahdîd ifade etmesi için fiilin başına gelmesi şart koşulmuştur (ibn Hişâm, 1985, ss. 95-97).

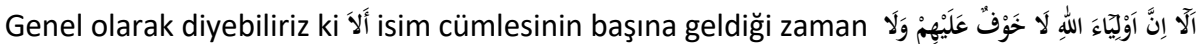
هُ هُمْ يَزَنَُونَ "Bilesiniz ki, Allah'ın dostlarına hiçbir korku yoktur. Onlar üzülmeyeceklerdir de" (Yûnus, 10:62) ayetinde olduğu gibi tenbîh ifade eder. Fiil cümlesinin başına geldiği zaman ise arz ve tahdîd ifade eder. Edatın taşıdığı diğer anlamların da arz ve tahdîdle bağlantılı olduğunu söyleyebiliriz. Bu edat Kurân-ı Kerim'de en çok kullanılan tahdîd edatlarındadır. Durum böyle olmakla birlikte bu edatın ifade ettiği tahdîd anlamının Türkçe meallerin ${ }^{3}$ birçoğunda yansıtılmadığını görmekteyiz. Bu edat ve diğer tahdîd edatlarıyla ilgili olarak bazı meallerden örnekler zikredeceğiz. Bu örnekleri zikrederken de ilk olarak tahdîd üslûbunu yansıtmaya çalıştığımız çeviriyi verip daha sonra örnek mealleri vereceğiz. Burada bazı mealler seçilmiş olmakla birlikte benzer durumlar diğer Türkçe mealler içinde söz konusudur.

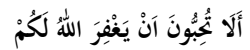

"Haydi Allah’ın sizi bağışlamasını istesenize!" (en-Nûr, 24:22).

Kuran Yolu Meali: “Allah'ın sizi bağışlamasını arzu etmez misiniz?”

3 Ayetlerin Türkçe mealleri https://www.kuranmeali.com/index.php adlı sitede verilen yaklaşık kırk meal üzerinden incelenmiştir. (Erişim tarihi: 30.06.2021). İlgili sitede yer alan ve yer almayan yukarıdaki diğer bazı meallerde örnek olarak verilmiştir. (Karaman vd., 2017; Feyizli, 2017; İslamoğlu, 2012; Öztürk, 2011; Ateş, 1983). 
H. Tahsin Feyizli: “Allah'ın sizi bağışlamasını sevmez misiniz?”

M. İslamoğlu: “Hem Allah'ın sizi bağışlaması hoşunuza gitmez mi?”

M. Öztürk: "Siz de hata ve kusurlarınızın Allah tarafından affedilmesini istemez misiniz?"

S. Ateş: "Allah'ın sizi bağışlamasını sevmez misiniz?"

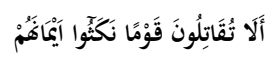

"Haydi! yeminlerini bozan bir kavimle savaşsanıza!" (et-Tevbe, 9:13).

Kuran Yolu Meali: "Yeminlerini bozan ... topluluğa karşı savaşmaktan geri mi duracaksınız?"

H. Tahsin Feyizli: “(Ey Mü’minler) Yeminlerini bozan ... bir toplumla (hâlâ) savaşmayacak mısınız?"

M. İslamoğlu: "Hâlâ sözlerini bozan ... bir toplulukla savaşmayacak mısınız?"

M. Öztürk: “(Ey Mü’minler) sizinle yaptıkları anlaşmaya uymayan ... bu namert adamlarla savaşmayacaksınız da başka kiminle savaşacaksınız?!"

S. Ateş: "Andlarını bozan ... bir kavimle savaşmayacak mısınız?"

Örnek olarak verdiğimiz birinci ayet, yukarıda zikri geçen meallerde ve diğer birçok mealde 4 genel olarak "istemez misiniz, arzu etmez misiniz?" şeklinde; ikinci ayet ise "savaşmaz mısınız, savaşmayacak mısınız?"5 şeklinde Türkçeye çevirilmiştir. Böyle bir çevirinin tahdîd üslûbunun ifade ettiği anlamı tam olarak yansıtmadığını düşünmekteyiz. Bunun sebebi iki farklı harften meydana gelen tahdîd edatlarının mürekkep halinin yeni bir mana ifade ettiğinin göz ardı edilmesi olduğunu söyleyebiliriz. Dolayısıyla bu üslûbun kullanıldığı ayetlerin, meâlini verdiğimiz gibi teşvik ifade edecek şekilde Türkçeye çevirilmesinin ayetin anlamını daha iyi yansıtacağı kanaatindeyiz.

Burada şu hususu da belirtmek istiyoruz ki, örnek olarak verdiğimiz meallerin çevirilerinin tamamen hatalı olduğunu söylemiyoruz. Ancak yukarıda tahdîd üslubuyla ilgili aktardığımız bilgilerden hareketle şunu görmekteyiz ki, bu üslûbun edatlarının özellikle fiili muzâriden önce kullanıldıkları zaman tahdîd ifade edeceği bu konuyu ele alan hemen hemen bütün dil kitaplarında aktarılmaktadır. Dolayısıyla aktardı̆ıımız bilgiler çerçevesinde burada tahdîd üslûbunu Türkçeye daha iyi yansıtabilme açısından bazı örnek çevirileri sunmaya çalışıyoruz. Bunun yanı sıra örnek olarak verdiğimiz mealler dışında bir

4 Ayetlerin Türkçe mealleri için bkz. https://www.kuranmeali.com/index.php (Erişim tarihi: 30.06.2021).

5 Ayetin tahdîd manasına sahip olduğu genel olarak çoğu tefsirlerde zikredilmiştir. Örnek için bkz. (erRâzî, 2000, ss. 187-189; el-Ḳurțubî, 2003a, s. 86). 
kısım meallerin bu üslûba dikkat ederek çeviriler yaptığını da görmekteyiz. Bu durumla ilgili bazı meallere de aşağıda vereceğimiz örnek ayetlerde temas etmeye çalışacağız.

Son olarak tahdîd ifade eden أَل edatıyla ilgili şunu da aktarabiliriz. Bu edat bazen fiili hazfedilmiş olarak da gelebilir. Amr b. Ki'âs el-Murâdî'nin aşağıdaki beyti buna örnek olarak verilmiştir: (el-Murâdî, 1992, s. 382).

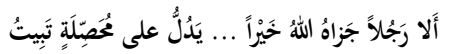

"Bana, benimle geceleyecek (evlenecek) altını kusurlarından arındıran (kıymetimi bilecek) bir kadına beni yönlendirecek bir adam -Allah onun hayrını versin- göstersene."

Beytin takdîri ise şَألا تُونني رَجُلاً şeklindedir.

\section{2. لَّ}

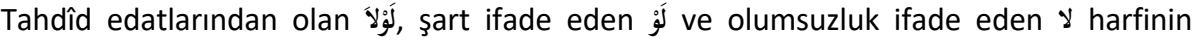
birleşmesiyle ortaya çıkan ve yeni bir anlam kazanan mürekkep bir edattır (ibnu's-Serrâc, t.y., s. 211). er-Rummânî iki farklı edattan mürekkep olan bu edatın tahdîd ve imtinâ ifade ettiğini söyler (er-Rummânî, 1425, ss. 174-176). Bu edatın genel olarak ise üç anlamı üzerinde durulur: İmtinâ, arz/tahdîd ve tevbih/tendim (Zeccâcî, 1984, s. 3; Ya'kûb \& Âsî, 1987b, ss. 1088-1089). لَّلَا edatı bu anlamlara ek olarak istifham ve nefiy de ifade etmektedir (Sa'd, 1988, ss. 415-419). Edatın ifade ettiği bu manaların ise arz/tahdîdle ilgili olduğu söylenebilir (es-Suyûț̂i, 1974, ss. 284-285).

Tahdîd ifade eden لَّ edatı farklı manalara sahip harflerle birleşerek yeni bir terkip oluşturmuştur. Bu yeni terkiple harflerdeki her iki mana da ortadan kalkmıştır. Hem isimlerle hem fiillerle kullanılan bu edat, imtinâ anlamında isimlerle kullanılmaya, tahdîd anlamında da fiillerle kullanılmaya has kıınmıştır (ibnu'ş-Şecerî, 2014b, ss. 297, 543).

Edatın sahip olduğu imtinâ anlamı, bir şeyin bulunmasından (veya bulunmamasından) dolayı başka bir şeyin bulunmaması (veya bulunması) durumunu ifade eder. İsim cümlelerinin başında kullanıldığı zaman bu anlamı kazanır (Ya'kûb \& Âsî, 1987b, s. 1089).

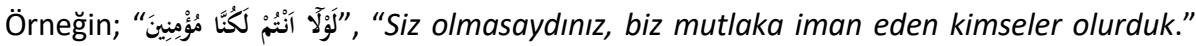
(Sebe', 34:31). Yani "sizin olmanız sebebiyle imanımız olmadı" şeklinde bir şeyin olmamasının sebebi başka bir şeyin varlığına bağlanmıştır.

Bu edat mâzî fiilin veya mâzî fiile tevil edilebilecek bir kelimenin başında kullanıldığı

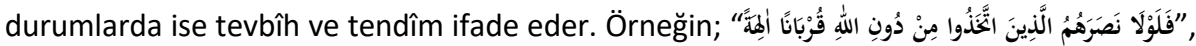
"Allah'tan başka kendilerine yakınlık sağlamak için ilahlar edindikleri şeyler, kendilerine

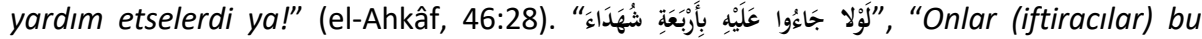


iddialarına dair dört şahit getirselerdi ya!" (en-Nûr, 24:13). Her iki ayete de baktığımız zaman muhatapları tevbîh ettiğini görüyoruz.

لَّ edatının imtinâ ve tevbîh dışında sahip olduğu esas anlam ise tahdîddir. Bu edat muzâri fiilin veya muzâri fiile tevil edilebilecek bir kelimenin başında kullanıldığı durumlarda tahdîd ifade eder. (el-Murâdî, 1992, ss. 605-606; Ya kûb \& Âsî, 1987b, s. 1089). Örneğin;

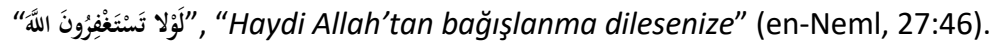

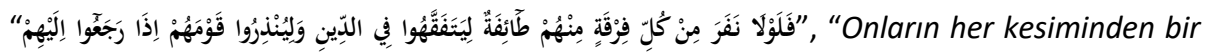
grup da din konusunda köklü ve derin bilgi sahibi olmak ve döndükleri zaman kavimlerini uyarmak için geri kalsa ya!" (et-Tevbe: 9:122) ayetinde لَّ edatı fili mâzînin başına gelmiş

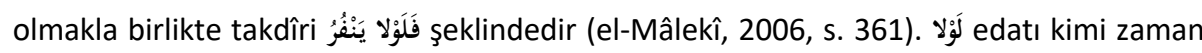
fiili hazfedilmiş ismin başına da gelir. Bu durumlarda da yine tahdîd ifade eder (el-Murâdî, 1992, s. 606). Örneğin, el-Eşheb b. Rumeyle'nin şu sözlerinde olduğu gibi.

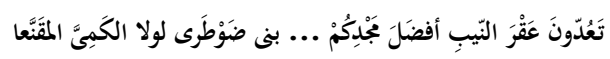

"Yaşlı, cılız develeri boğazlamayı en üstün şeref mi sayıyorsunuz, Ey Benî Davtara (silahlarına) bürünmüş yiğitleri (öldürmeyi şeref) saysanız ya!"

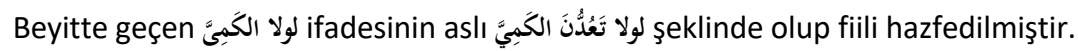

Bu edat Kurân-ı Kerîm'de yaklaşık yetmiş beş defa geçer. Bunlardan otuz dört tanesi ismin başında, otuz bir tanesi mâzî fiilin başında, on tanesi ise muzâri fiilin ${ }^{6}$ başında kullanılmıştır. لَّ edatının muzâri fiilin veya muzâri fiile tevil edilebilecek kelimelerin başına geldiği durumlarda tahdîd ifade ettiğini daha önce zikretmiştik. Dolayısıyla Kurân'da da benzer şekilde mâzî fiilin veya ismin başında kullanıldığı durumlarda da tahdîd ifade ettiği anlamlar söz konusudur. Ancak durum böyle olmakla birlikte bu üslûbun birçok meale yansıtılmadığını görmekteyiz. Bu duruma bazı ayetler üzerinden örnek vermeye çalışacağız.

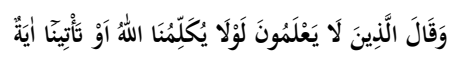

"Bilmeyenler, "Allah bizimle konuşsa ya da bize bir mucize gelse ya!" dediler" (el-Bakara, 2:118).

Kuran Yolu Meali: "Bilgiden yoksun olanlar, "Allah bizimle konuşmalı veya bize mucizeli bir işaret gelmeli değil miydi?" dediler."

6 Tahdîd ifade eden bu durumlar için bkz. (el-Bakara, 2:118; el-Mâide, 5:63; el-Kehf, 18:15; Tâhâ, 20:133; en-Neml, 27:46; el-Vâkıâ, 56:57, 62, 70; el-Mücâdele, 58:8; el-Kalem, 68:28). 
H. Tahsin Feyizli: "(Ehl-i Kitab ve müşriklerden birtakım) bilgi yoksunları: "Allah (senin peygamberliğin hakkında) bizimle konuşmalı ya da bize bir âyet (mucize) gelmeli değil miydi?" dediler."

M. İslamoğlu: "ilimden yoksun olanlar "Allah bizimle niçin konuşmuyor, ya da niçin bize mucizevi bir belge ulaştırmıyor" derler."

M. Öztürk: Hiçbir ilâhî bilgiye sahip olmayan müşrikler de (geçmişteki Yahudilere öykünürcesine,) "Allah bizimle konuşsa ya da bize bir mucize gelse olmaz mıydı?!" diyorlar."

S. Ateş: "Bilmeyenler dediler ki: "Allah bizimle konuşmalı, ya da bize bir ayet (mu'cize) gelmeli değil miydi?"

Kurtûbî (ö. 671/1273) ayetteki لَّ edatının tahdîd için geldiğini söyler. Manasının ise "Haydi Allah Muhammed'in peygamberliğiyle ilgili bizimle konuşsun veya onun peygamberliğine işaret eden bir mucize göndersin de biz de onun peygamber olduğunu bilelim ve inanalım" şeklinde tahdîd ifade ettiğini zikreder (el-Kurțubî, 2003b, s. 92). Bununla birlikte birçok mealde "konuşmalı değil miydi, mucize gelmeli değil miydi" şeklinde Türkçeye çevirildiğini görmekteyiz. Her ne kadar bu şekilde yapılan bir meal dolaylı yönden tahdîd anlamına yakın olsa da bu üslûbu tam olarak yansıtmadığını söyleyebiliriz. Bunun yanı sıra tahdîd üslûbunu göz önünde bulundurarak yapılan çeviriler de mevcuttur. Örneğin Diyanet İşleri Başkanlığı mealinde ilgili ayet "Bilmeyenler, "Allah bizimle konuşsa, ya da bize bir mucize gelse ya!" derler" (Altuntaş \& Şahin, 2011) şeklinde Türkçe'ye aktarılmıştır. Bu çeviride tahdîd üslûbunun ifade ettiği anlamı görmekteyiz.

Bu edatla ilgili bir diğer örnek olarak şu ayeti verebiliriz:

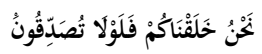

"Sizi biz yarattık, haydi tasdik edip inansanıza!" (el-Vâkıa, 56:57).

Kuran Yolu Meali: "Sizi biz yarattık, artık inansanıza!"

H. Tahsin Feyizli: "Sizi biz yarattık. O halde tasdik etmeniz gerekmez mi?"

M. İslamoğlu: "Sizi yaratan Biziz; o halde (ey insanlar), bu gerçeği neden hâlâ kabullenmezsiniz?"

M. Öztürk: "(Ey Kâfirler!) Sizi yaratan biziz, biz! Hâla tevhid gerçeğini kabul etmeyecek misiniz?!"

S. Ateş: "Biz sizi yarattık; tasdik etmeniz gerekmez mi?"

ez-Zemahşerî (öl. 538/1144) ayetteki لَّ edatının, ayetteki tasdik edilmesi istenen şeyi tahdîd için geldiğini söyler. Tasdik edilmesi istenen şey ya yaratmadır -yani onlar her ne 
kadar tasdik ediyor gibi olsalar da tasdiğin gerektirdiğinin aksine bir yol tutmuşlar; böylece sanki yaratılışı inkâr edenler gibi olmuşlardır- ya da yeniden dirilmedir. Çünkü ilk kez yaratanın ikinci kez yaratması imkansız değildir (ez-Zemahş̧erî, 1407a, s. 465). Dolayısıyla ayette her iki durumu tasdik edip onaylamaya bir tahdîd/teşvik vardır. Zikri geçen ayetin devamında yine bu üslûba ait bir kullanım olduğunu görmekteyiz:

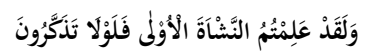

"Şüphesiz, birinci yaratılışı(nızı) biliyorsunuz. Öyleyse (bunun üzerine) düşünüp ibret alsanız ya!" (el-Vâkıa, 56:62).

Kuran Yolu Meali: "Hiç kuşkusuz ilk yaratılışınızı biliyorsunuz; düşünüp ibret alsanıza!"

H. Tahsin Feyizli: "Andolsun ki ilk yaratılışı(nızı) bildiniz. O halde (öldükten sonra da yeniden diriltileceğinizi) düşünmeniz gerekmez mi?"

M. İslamoğlu: "Doğrusu ilk yaratılış (mucizesini) bilmiş olmanız lazım; o halde neden (ikinci yaratılış hakkında) ibret almıyorsunuz?"

M. Öztürk: "Siz ilk yaratılışın nasıllığını pekâlâ biliyorsunuz. Öyleyse yeniden diriltmeye muktedir olduğumuzu niçin düşünmüyorsunuz?!"

S. Ateş: "Andolsun, ilk yaratmayı bildiniz, (bunu) düşünüp ibret almanız gerekmez mi?”

Her iki ayete baktığımız zaman bunlardan birincisinin genellikle "tasdik etmeyecek misiniz, tasdik etmeniz gerekmez mi, kabul etmeyecek misiniz?" şeklinde; ikincisinin ise "düşünüp ibret almanız gerekmez mi, niçin düşünmüyorsunuz?” şeklinde meallere yansıdığını görmekteyiz. Verilen bu anlamlar dolaylı olarak tahdîd üslûbunu yansıtsa da tam anlamıyla yeterli olmadığını söyleyebiliriz. Bunun yanı sıra örnek olarak verdiğimiz Kuran Yolu Meali'nde görüldüğü üzere tahdîd üslûbu göz önünde bulundurularak çeviri yapılmıştır. Ayrıca Diyanet İşleri Başkanlığı Meali'nde de yukarıda örnek olarak verdiğimiz Vâkıa suresi 62. ayet "Andolsun, birinci yaratılışı(nızı) biliyorsunuz. O hâlde düşünseniz ya!" (Altuntaş \& Şahin, 2011) şeklinde tahdîd üslûbuna uygun şekilde çevirilmiştir. Sonuç olarak ilgili ayetlerin meallerinin yukarıda mealini verdiğimiz şekilde Türkçeye çevirilmesinin daha isabetli olacağı kanaatindeyiz.

\section{3. ألاًَ وَهَلًَا}

Diğer tahdîd edatları gibi الَا لهَلَّ da fiillerin başına geldiği zaman tahdîd anlamı ifade eder. ألاً edatının aslının olduğu, ha (ه) harfinin hemzeye (أ) dönüştüğü ve bazı Arapların bu edatları birbirinin yerine kullandığı da söylenmektedir (er-Rummânî, 1425, s. 188; elMurâdî, 1992, ss. 509, 613). es-Suyûtî (ö. 911/1505) ألاً 'nın tahdîd harflerinden olduğunu söyler ve Kurân'da bu anlamda hiç kullanılmadığını aktarır (es-Suyûțî, 1974, s. 189). 
Bununla birlikte oهَ edatının ise en çok kullanılan tahdîd edatlarından birisi olduğunu

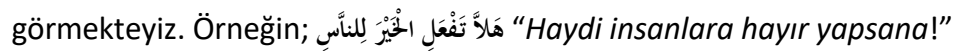

Bazı dilciler tahdîd edatlarından sonra isim cümlesinin de gelebileceğini caiz görmüşlerdir (el-Murâdî, 1992, ss. 509, 613). Bu anlamda oَّ ile ilgili es-Sımat b. Abdullah el-Kuşeyrî́nin beyti örnek olarak çokça zikredilmektedir:

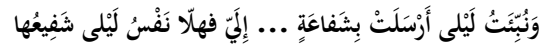

"Leylânın bir şefaatçi gönderdiği haber verildi bana. Keşke Leylânın kendisi şefaatçisi olsaydı ya!"

Beytin takdîri فهلّا تَكونُ نَفْسُ كَيْلى شَفِيعُها "Leylânın kendisi şefaatçisi olsaydı ya!" şeklindedir.

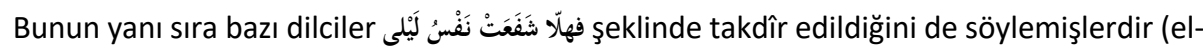
Murâdî, 1992, s. 613). Aynı durumla ilgili bir başka örnek ise şu beyittir:

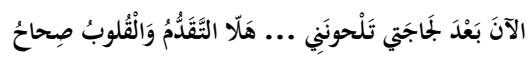

\section{"Inadımdan ve öfkemden sonra mı beni kınıyorsun? Kalp bütün kötülüklerden uzakken} gelseydin ya!"

Beyitte هَ tahdîd edatından sonra isim gelmiş olup tahdîd edatıyla isim arasına كانَ fiili takdîr etmiştir.

\section{4. لَوَ}

Tahdîd edatlarından son olarak ele alacağımız log edatıdır. el-Mâlikî (ö. 706/1307) Rasfu'lMebânî adlı eserinde bu edatın Araplarda sadece tahdîd anlamında kullanıldığını ifade etmiştir. Ona göre, tahdîdde talep anlamı olduğundan, talep de ancak fiillerle ifade edildiğinden bu edat sadece fiillerin başına gelir. Örneğin, لَوْما يَقومُ زَيْدُ "Zeyd kalksa ya!" Eğer

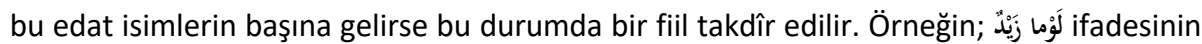
aslı لَوَما يُكْرُمُ زَيْدُ "Zeyd ikram etse ya!" şeklinde veya bunun benzeri konuşmaya uygun bir fiil takdîr edilecek şekildedir (el-Mâlekî, 2006, ss. 365-366).

er-Rummânî de bu edatın ơ edatıyla aynı anlamda kullanılıp tahdîd ifade ettiğine değinmektedir (er-Rummânî, 1425, s. 177). İbnu'ş-Şecerî el-Emâlî adlı eserinin altmış sekizinci meclisinde o edatının durumlarını aktarırken tahdîd edatlarından لَ edatına da değinmiştir. Ona göre, w edatı gُ edatıyla birleşerek bu edatın asıl manasını değiştirmiştir. Böylece وَ bir şeyin olması için başka bir şeyden sakındırmak anlamında kullanılırken artık tahdîd anlamını almıştır (ibnu'ş-Şecerî, 2014b, s. 598). 
Bu edatın tahdîd edatlarından لَّ ile kullanım bakımından aynı olduğu da aktarıımıştır (esSuyûțî, 1974, s. 286; Ya'kûb \& Âsî, 1987b, s. 1090). el-Murâdî (ö. 749/1348) Loو edatının iki anlamı olduğunu söyler. Bunlardan birincisi diğer edatlarda da olduğu gibi imtinâ

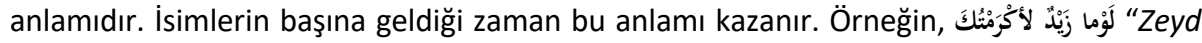
olmasaydı sana ikram ederdim" cümlesinde bir şeyin olmaması başka bir şeyin olmasına bağlanmıştır. Bu edatın ikinci anlamı ise tahdîddir. Diğer tahdîd edatlarında olduğu gibi fiilin veya fiili gibi amel eden mamûlun başına geldiği durumlarda bu anlamı kazanır (elMurâdî, 1992, ss. 608-609). Bu edat Kurân-ı Kerîm'de tek bir yerde geçer:

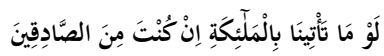

“Eğer doğru söyleyenlerden isen haydi bize melekleri getirsene!" (el-Hicr, 15:7).

Kuran Yolu Meali: “Doğru söyleyenlerden isen bize melekleri getirseydin ya!"

H. Tahsin Feyizli: "Eğer doğru söyleyenlerden isen ne diye bize melekleri getirmiyorsun?"

M. İslamoğlu: "Eğer doğru söylüyor idiysen, bize meleklerle gelseydin ya!"

M. Öztürk: "Mademki peygamberlik iddianda samimisin, o halde niçin bize melekleri getirip göstermiyorsun!"

\section{S. Ateş: "Eğer doğrulardansan, bize melekleri getirsene!"}

ez-Zemahşerî ayetteki لَّمَ edatının gَ gibi tahdîd ifade ettiğini manasının da "haydi bize melekler getirsene, doğruluğuna şahitlik etsinler, uyarılarını da desteklesinler" şeklinde olduğunu zikreder (ez-Zemahşserî, 1407b, s. 571). لَّ edatının ayette tahdîd ifade ettiğine dair benzer ifadeleri Kurtûbî de zikretmiştir (el-Ḳurțubî, 2003c, s. 4).

Zikri geçen ayetin meallerdeki çevirisine baktığımız zaman meallerin bir kısmında "neden bize melekleri getirmiyorsun, getirmeli değil miydin?" şeklinde istifhâmî olarak aktarıldığını görüyoruz. Bununla birlikte diğer tahdîd edatlarından farklı olarak woو edatında birçok mealde tahdîd anlamını gözetilerek "bize melekleri getirsene!" şeklinde anlam verildiğini de görmekteyiz. Bu duruma Kurân'daki tek örnek olmasının etkili olduğunu söyleyebiliriz. Kanaatimizce bu manaya yakın "Eğer doğru söyleyenlerden isen haydi melekleri bize getirsene!" şeklinde bir anlamın verilmesi daha uygun olacaktır.

\section{Sonuç}

Tahdîd üslûbu, muhataptan bir şeyi yapmasını veya yapmamasını güçlü bir şekilde istemektir. Arap dilinde belli edatlar kullanılarak cümleye tahdîd anlamı katılır. Tahdîd

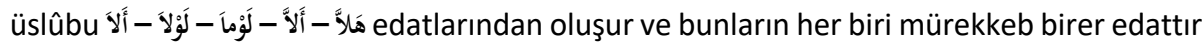
ve her biri ayrı ayrı harflerin birleşmesinden oluşmuştur. Bu edatların tahdîd ifade etmeleri için zâhiren veya takdîren muzâri fiilin başına gelmesi gerekir. Bunun yanı sıra mâzi fiilin 
başına geldiği durumlarda cümle tahdîd anlamında kullanılmışsa mâzî fiil muzâriye hamledilir. Ayrıca cümledeki üslûbun tahdîd ifade etmesi kullanılan kelimelerden, vurgulamadan ve bağlamdan da anlaşılır.

Arap dilinde zikri geçen edatlarla tahdîd üslûbu yapılmakla birlikte bunların Türkçeye çevirilmesinde problemler olduğu görülmektedir. Bu sorunun temelinde tahdîd edatlarının mürekkep halinin yeni bir mana ifade ettiğinin göz ardı edilmesi yatmaktadır. Durum böyle olunca bu üslûbun araştırmamızda da ortaya koyduğumuz gibi Türkçeye daha çok istifhâm/soru cümlesi şeklinde çevirildiğini görmekteyiz. Ayrıca Arapçada böyle bir üslûbun olmasından habersiz olarak meâllerin ortaya konması da bu sorunun diğer bir sebebi olarak gösterilebilir.

Bu bağlamda çalışmamızda bu üslûbu mealler üzerinden Türkçeye nasıl yansıtıldığını incelemeye çalıştık. Bu anlamda toplumda yaygın olarak kullanıldığını gördüğümüz beş meali örnek olarak verdik. Bununla birlikte diğer meallere de temas etmeye çalıştık. Meallerin genelinde tahdîd üslûbuna dikkat edilmediğini görmekteyiz. Durum böyle olmakla birlikte verilen meallerin tamamen yanlış olduğunu da söyleyemeyiz. Zira genel olarak tahdîd edatlarının mürekkep halinin kazandığı yeni anlama dikkat edilmeden soru cümlesi şeklinde çevirilen cümlelerin istifhâm üslûbunun içerdiği ve dolaylı olarak da tahdîd üslûbuyla bağlantılı olduğunu söyleyebileceğimiz şekilde Türkçeye aktarıldığını görmekteyiz. Ancak böyle bir çevirinin de üslûbun içerdiği anlamı tam olarak yansıtmadığı düşünmekteyiz. Bunun yanı sıra bazı meallerde bu üslûp göz önünde bulundurularak çeviri yapılmıştır. Bunlara çalışmamızın ilgili yerlerinde temas etmeye çalıştık.

Son olarak şunu söyleyebiliriz ki, tahdîd üslûbunun özelliklerini taşıyan cümlelerin Türkçeye çevirisinde bu üslûpta var olan teşvik anlamının cümleye yansıtılması gerektiği kanaatindeyiz. Bu anlamda tahdîd üslûbu Türkçeye çevirilirken cümlenin baş kısmına "Haydi, hadi" gibi ifadeler, sonuna da "-sene, -sana, -senize, -sanıza, -senize ya, -sanıza ya $v b . "$ eklerin eklenerek aktarılmasının, bu üslûbun ifade ettiği anlamı daha iyi yansıtacağını söyleyebiliriz.

\section{Kaynakça}

Altuntaş, Halil, \& Şahin, Muzaffer. (2011). Diyanet İ̧̧leri Başkanlığı Kur'ân-ı Kerim Meâli (12. bs).

Ateş, Süleyman. (1983). Kur'ân-ı Kerîm ve yüce meâli. Kılıç Kitabevi.

Feyizli, Hasan Tahsin. (2017). Feyzü'l-Furkân (6. bs). Server Yayınları.

Feyyûmî, Ebü'l-Abbâs Hatîbüddehşe Ahmed b. Muhammed b. Alî. (t.y.). el-Misbâhu'lmünîr. Yûsuf eş-Şeyh Muhammed (thk.). el-Mektebetu'l-Asriyye.

Ḥasan, Abbâs. (t.y.). en-Naḥvu'I-vâfí (C. 4). Dâru'I-Maârif. 
Huriye bt. Müferrec Sa'dî. (2012). -Levlâ- rnvâuhâ ve ahkâmuhâ'n-nahviyye, Mecelletu Kulliyyeti Dâru'I-Ulûm.

İbn Fâris, Ebü'l-Hüseyn Ahmed b. Fâris b. Zekeriyyâ b. Muhammed er-Râzî el-Kazvînî elHemedânî. (1997).eș-Ṣâhibî fí fıḳhi'l-lug̉a, Muhammed Beydûn (thk.).

İbn Hişâm, Ebû Muhammed Cemâlüddîn Abdullâh b. Yûsuf b. Ahmed b. Abdillâh b. Hişâm el-Ensârî el-Mısrî. (1985). Muġni'l-lebîb 'an kutubi'l-e'ârîb. Mâzin Mübârek (thk.). Dâru'l-Fikr.

İbn Manz̧ûr, Ebü’l-Fazl Cemâlüddîn Muhammed b. Mükerrem b. Alî b. Ahmed el-Ensârî erRüveyfiî. (1414). Lisânü'l-'Arab (C. 7). Dâru Sadr.

İbnu's-Serrâc, Ebû Bekr Muhammed b. es-Serî b. Sehl el-Bağdâdî. (t.y.). el-Ușûl fi'n-naḥv (C. 2). Abdulhuseyn el-Fetlî (thk.). Müessestu'r-Risâle.

İbnu'ş-Şecerî, Ebü's-Saâdât Ziyâüddîn Hibetullah b. Alî b. Muhammed b. Hazma el-Hâşimî el-Alevî el-Hasenî el-Bağdâdî. (2014a). el-Emâlî (C. 1). Mahmûd Muhammed et-Tanâhî (thk.).

İbnu'ş-Şecerî, Ebü's-Saâdât Ziyâüddîn Hibetullah b. Alî b. Muhammed b. Hazma el-Hâşimî el-Alevî el-Hasenî. (2014b). el-Emâlî (C. 2). Mahmûd Muhammed et-Tanâhî (thk.).

İslamoğlu, Mustafa. (2012). Hayat Kitabı Kur'an Gerekçeli Meal-Tefsir (13. bs). Düşün Yayıncılık.

Karaman, Hayreddin, Çağrıcı, Mustafa, Dönmez, İbrahim Kâfi, \& Gümüş, Sadrettin. (2017). Kuran Yolu Meâli (7. bs). Diyanet İşleri Başkanlığı Yayınları.

Kurțubî, Ebû Abdillâh Muhammed b. Ahmed b. Ebî Bekr b. Ferh. (2003a). el-Câmi liaḥkâmi'l-Kur'ân (C. 8). Hişâm Semîr el-Buhârî (thk.). Dâru Alemi'l-Kutub.

Ḳurțubî, Ebû Abdillâh Muhammed b. Ahmed b. Ebî Bekr b. Ferh. (2003b). el-Câmi' liaḥkâmi'I-Kur'ân (C. 2). Hişâm Semîr el-Buhârî (thk.). Dâru Alemi'I-Kutub.

Ḳurțubî, Ebû Abdillâh Muhammed b. Ahmed b. Ebî Bekr b. Ferh. (2003c). el-Câmi` liạ̣kâmi'l-Kur'ân (C. 10). Hişâm Semîr el-Buhârî (thk.). Dâru Alemi'l-Kutub.

Mâlekî, Ebû Ca'fer Ahmed b. Abdinnûr b. Ahmed b. Râşid. (2006). Rașfu'l-mebânî fí şerḥi ḥurûfi'l-meânî. Aḥmed Muḥammed el-Harrât (thk.). Dâru'I-Kalem.

Muhammed Hâlid Abdurrâhmân Ahmed, Abdusselâm Muhammed Abdurrâhîm, Zâhiratu'-tahdîd fi'l-lugati'l-Arabiyye dirâsetun vasfiyyetun tahlîliyyetun fí dav'il'Kurâni'I-Kerîm. 
Murâdî, Ebû Muhammed (Ebû Alî) Bedrüddîn Hasen b. Kâsım b. Abdillâh b. Alî. (1992). elCene'd-dânî fî ḥurûfi'l-me'ânî. Fahreddîn Kabâve, Muhạammed Nedîm Fadl (thk.). Dâru'l-Kutubi'l-ilmiyye.

Mürevvihh Nâyif Hasan er-Rıfâi. (2011). Esâlîbu'l-Arz ve't-Tahdîd ve't-tenbîh: Dirâsetun Nahviyyetun Delaliyyetun fi'I-Kurâni'I-Kerîm (Yüksek Lisans).

Öztürk, Mustafa. (2011). Kur'an-ı Kerim meali anlam ve yorum merkezli çeviri (1. bs). Düşün Yayıncılık.

Râzî, Ebû Abdillâh (Ebü'l-Fazl) Fahrüddîn Muhammed b. Ömer b. Hüseyn. (2000). Mefâtîhu'l-ġayb (C. 31). Dâru'I-Kutubi'l-ilmiyye.

Rummânî, Ebü'l-Hasen Alî b. Îsâ b. Alî. (1425). Meâni'I-hurûf. el-Mektebetu'I-Asriyye.

Sa'd, Mahmûd Abdunnebî. (1988). Hurûfu'I-Meânî beyne dekâiki'n-nahv ve letâifi'l-fıkh.

Sekkâkî, Ebû Ya'kûb Sirâcüddîn Yûsuf b. Ebî Bekr (b.) Muhammed b. Alî el-Hârizmî. (1987). Miftâhu'I-'ulûm. Dâru'I-Kutubi'I-ilmiyye.

Suyûțî, Ebü'l-Fazl Celâlüddîn Abdurrahmân b. Ebî Bekr b. Muhammed el-Hudayrî. (1974). el-itkân fí 'ulûmi'l-Ḳurân (C. 2). el-Heyetu'I-Mısriyyetu'I-Amme.

Ya'kûb, Emil Bedî', \& Âsî, Mişâl. (1987a). el-Mu'cemu'I-mufașșal fi'l-luġati ve'l-edebi (C. 1). Dâru'l-illmi li'|-Melâyîn.

Ya'kûb, Emil Bedî', \& Âsî, Mişâl. (1987b). el-Mu'cemu'I-mufașșal fi'l-lugiati ve'l-edebi (C. 2). Dâru'I-illmi li'l-Melâyîn.

Zebîdî, Ebü'l-Feyz Muhammed el-Murtazâ b. Muhammed b. Muhammed b. Abdirrezzâk el-Bilgrâmî el-Hüseynî. (t.y.). Tâcü'l- 'arûs min cevâhiri'l-kâmûus (C. 18). Dâru'I-Hidâye.

Zeccâcî, Ebü'l-Kâsım Abdurrahmân b. İshâk en-Nihâvendî. (1984). Hurûfü'l-me'ânî. Ali Tevfîk el-Hamed (thk.). Müessestu'r-Risâle.

Zemahşerî, Ebü'I-Kâsım Mahmûd b. Ömer b. Muhammed el-Hârizmî. (1407a). el-Keşşâf (C. 1). Dâru'I-Kitâbi'I-Arabî.

Zemaḩşerî, Ebü'I-Kâsım Mahmûd b. Ömer b. Muhammed el-Hârizmî. (1407b). el-Keşşâf (C. 2). Dâru'I-Kitâbi'I-Arabî. 